\title{
The Influence of Digital Marketing Literacy on Entrepreneurship Behavior among Public University Students in Malaysia
}

\section{Thennarasi Moorthy \& Sheerad Sahid}

To Link this Article: http://dx.doi.org/10.6007/IJARBSS/v12-i1/11837

DOI:10.6007/IJARBSS/v12-i1/11837

Received: 09 November 2021, Revised: 14 December 2021, Accepted: 27 December 2021

Published Online: 15 January 2022

In-Text Citation: (Moorthy \& Sahid, 2021)

To Cite this Article: Moorthy, T., \& Sahid, S. (2021). The Influence of Digital Marketing Literacy on Entrepreneurship Behavior among Public University Students in Malaysia. International Journal of Academic Research in Business and Social Sciences, 12(1), 548 - 568.

\section{Copyright: $\odot 2022$ The Author(s)}

Published by Human Resource Management Academic Research Society (www.hrmars.com) This article is published under the Creative Commons Attribution (CC BY 4.0) license. Anyone may reproduce, distribute, translate and create derivative works of this article (for both commercial and non0-commercial purposes), subject to full attribution to the original publication and authors. The full terms of this license may be seen at: http://creativecommons.org/licences/by/4.0/legalcode

$$
\text { Vol. 12, No. 1, 2022, Pg. } 548 \text { - } 568
$$




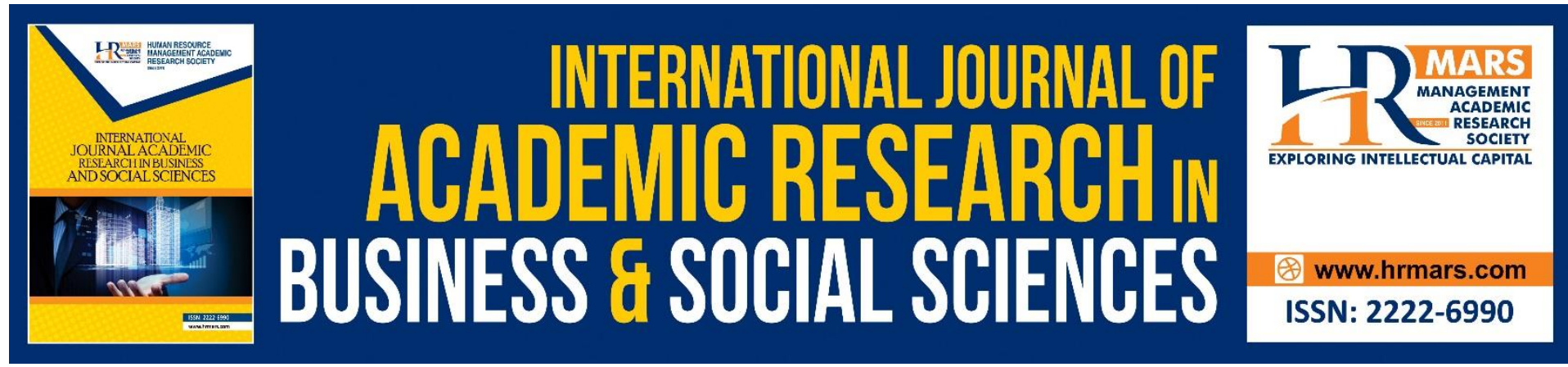

\title{
The Influence of Digital Marketing Literacy on Entrepreneurship Behavior among Public University Students in Malaysia
}

\author{
Thennarasi Moorthy \& Sheerad Sahid \\ Faculty of Education, National University of Malaysia (UKM)
}

\begin{abstract}
This study examines the relationship between the dimensions of digital marketing literacy (the knowledge of digital marketing literacy level, understanding of respondents' digital participation tendencies related to entrepreneurial information, and the knowledge of the elements of digital marketing) and entrepreneurial behavior (entrepreneurial tendencies and interests, attitudes in starting a business, and behavioural control) among Public University students in Malaysia. This study is explanatory research in which the goal is to discover and explain causal links between variables. Furthermore, this research is being carried out to address the issues that have been raised, to meet stated objectives, and to test the hypothesis. This study used the survey method to collect data by distributing questionnaires, and the research approach was quantitative. The data was gathered from 384 respondents and analyzed using the Statistical Package for the Social Sciences (SPSS) version 21.0. The descriptive, reliability, normality, correlation and multiple regression analyses were employed to analyse the data. The results show that digital marketing literacy among Public University students in Malaysia is at a moderate level in influencing entrepreneurial behavior. The results also show that there is a positive and significant relationship between digital marketing literacy and entrepreneurial behaviour among Public University students in which the knowledge of the elements of digital marketing is found to be the most influential dimension towards entrepreneurial behavior. The implication of this study to promote awareness among the Public University students in Malaysia about digital marketing literacy on entrepreneurial behavior. This study would also provide insights to the university on what should be done to increase digital literacy and encourage entrepreneurial behavior among the students.
\end{abstract}

Keywords: Digital Marketing Literacy, Entrepreneurial Behavior, Social Learning Theory, Theory of Planned Behavior, Public University Students

\section{Introduction}

In the era of globalization, the development of technology today is driving a change in the style of the marketing world which is more inclined towards the era of digital marketing. The digital, social media, and mobile marketing continue to evolve with technological innovations such as affordable high -speed broadband connections, widespread consumer use of mobile devices, and the expansion of social media platforms such as Facebook. With 
these innovations, consumer behavior in various types of markets is also changing. One example is social media, which has changed the way shoppers interact with brands and share information with other users. Thus, new technologies have simplified market behavior, interaction, and experience, but also transformed traditional marketing into a digital form (Lamberton \& Stephen, 2016).

Yet, according to Lamberton and Stephen (2016), we are swiftly reaching the "postdigital" future of marketing, which will supplant the age when marketing was separated into digital and conventional. As a result, digital marketing should be referred to simply as marketing because practically all marketing efforts undertaken by businesses now include a digital component (Lamberton \& Stephen, 2016). Nonetheless, according to Taiminen and Karjaluoto (2015), marketers should be aware of the unique characteristics of digital marketing in order to choose efficient marketing approaches and strategies. This is because digital marketing is an entirely new approach to marketing, not merely conventional marketing with digital features (Taiminen \& Karjaluoto, 2015).Most of the digital marketing literacy studies conducted are focused on consumers only. While studies on the relationship between digital marketing literacy and entrepreneurial behavior of students are very limited. Therefore, the purpose of this study is to link digital marketing literacy with student entrepreneurial behavior public university in Malaysia. This study serves to raise awareness of digital marketing literacy on entrepreneurial behavior Public University students can be empowered.

In view of the above, the objective of this study is:

- to identify the influence of digital marketing literacy on student entrepreneurial behavior.

\section{The dimensions of Digital Marketing Literacy}

Knowledge of digital marketing literacy level

Digital literacy refers to the meaning -making that occurs as students interact by reading, analyzing, understanding, and responding to the Education Development Center (EDC) and multimodal form of digital content. In defining the concept of digital literacy, some authors tend to understand it as relating to the skills and competencies required for effective use of the Internet and digital technology (Cartelli, 2010; Ala-Mutka, 2011). Martin (2005) argues that digital literacy involves the convergence of several types of literacy: information technology literacy, media literacy, and visual literacy that acquire new or increasingly important roles with the advent of the digital environment. Every author who adheres to similar perceptions has shifted from focusing on specific skills to realizing that literacy is a more integrative quality linked to the use of skills and competencies in the context of real life tasks or problems (Martin, 2005).

Thus, researchers can conduct a wide range of methodological studies into the accessibility of digital technology and the achievement/impact of digital empowerment, taking into consideration important conceptual and practical factors. There is no simple path to digital empowerment. Methodological approaches to growth in general, and inclusive growth in particular, will continue to evolve and should adapt to functional changes, technological advancements, and human perspectives on growth. In recent years, digital literacy studies have emphasized the need to go beyond basic skills in using tools and information resources. Digital literacy develops strategies for the critical and efficient use of these methods. That's why most researchers view this literacy as a "continuum, with a progressive level where basic abilities are only the first step. The top end of the continuum 
contains increased levels of cognitive ability in using literacy intended for tasks, learning, creating, and expressing new ideas involving issues such as attitudes, social and cultural aspects" (Ala-Mutka, 2011).

Moreover, all marketing initiatives that involve an electronic device or the internet are referred to as digital marketing. To engage with present and potential customers, businesses use digital channels such as search engines, social media, email, and their websites. It's also known as 'online marketing,' 'internet marketing,' or 'web marketing.' Digital marketing is described as the use of a variety of digital methods and platforms to reach out to clients where they spend the majority of their time: online. There's a spectrum of strategies that fit under the name of "digital marketing," from websites to business's online branding, assets-digital advertising, email marketing, online brochures, and beyond. Digital marketing is based on the most frequently used internet channels; they are dynamic, can vary from year to year, and are always influenced by market trends. This form of digital marketing has had a significant impact on sales and customer numbers, influencing, at best, commercial tendencies (Zenebe et al., 2017).

\section{Understanding of respondents 'digital participation tendencies related to entrepreneurial} information.

Digital transformation is radically changing the function and processes of the businesses. Therefore, to ensure the entrepreneurs become inclusive in their digital businesses, they would adopt digital technologies to improve their business processes (Organisation for Economic Cooperation and Development (OECD) 2019). In fact, digital transformation is the basic drivers of the business innovation system, especially in evaluating future opportunities. Despite the fact that the digital transformation is the result of entrepreneurs participating in the digital world, they face a dilemma in regard to the availability and distribution of resources in the business. Hence, studies show that by adopting digital technologies, the entrepreneurs need to constantly learn and understand the knowledge of information technology to enhance their business performance (Zenebe et al., 2017).

Moreover, today's businesses spend a lot of money on new technology to become more efficient, competitive, and, most importantly, profitable. However, one element that frequently stymies the introduction and acceptance of new technologies in the workplace is the opposition and attitude of end users and other employees who are expected to use them. Companies frequently invest a lot of time, money, and effort into new technology only to discover that their staff either don't use them or don't know how to use them. If employees believe that new technology will help them perform better in their employment, they have a higher behavioral intention to use it in the workplace staff must be correctly trained on any new systems in order to understand the importance and relevance of new technology. Despite studies into the elements that influence employees' attitudes toward new technology, businesses continue to struggle with the successful implementation of IT. Studies showed that the entrepreneur's understanding of the elements is important to influence acceptance of new technology (Wong et al., 2018)

The digital world creates a competitive scenario in which entrepreneurs may find it advantageous to adopt an entrepreneurial strategic stance. Because companies are expected to maintain a competitive advantage by demonstrating innovative, proactive, and risk-taking efforts, the use of digital technologies opens up new ways to improve current entrepreneurial orientation by optimizing processes, managerial, and strategic decisions (market entry, customer targeting, partnership, pricing decisions), and customization. Digital technologies create more variability in entrepreneurial activities and allow them to rapidly and easily 
enhance their capabilities and performance to create value (Lumpkin \& Dess, 2004; Nambisan, 2017). The understanding of respondents 'digital participation tendencies related to entrepreneurial information plays a major role to sustain in the industry.

Knowledge of the elements of digital marketing.

Kamal (2016) showed that digital marketing has evolved rapidly ever since the internet was created in the year 1989. Statistics showed developed economies such as Australia,United States and Luxembourg practices digital marketing to their full capacity, to acquire a return on investment on marketing spending. As a result, this led to various elements of digital marketing. The elements include search engine optimization (SEO), pay per click advertising (PPC), web banner advertising, pop-ups, Search Engine Marketing (SEM), sponsored search, social media marketing, mobile advertising, affiliate marketing, online classified advertising, and email marketing (Malik, 2017).

Nevertheless, business industries can utilize a variety of strategies to generate more cash, allowing them to explore new horizons of growth and expansion, political parties, for example, are utilizing the option of mobile in mass communication (which is one side of digitalization). However, other systems are incorporating biometrics into identification, while marketers are incorporating digital systems and elements to monitor customer satisfaction, as well as in record customer feedback. There is utility based on the need at all times, and a few wanted and significant uses of digital marketing include identifying customer needs through digital marketing and using digital mechanisms to track customer feedback and logistics purposes digital marketing can be added as upgradations. The study shows business organizations are targeting SEO efforts and compensated search advertising for enhancing the traceability of their merchandise and services which emphasizes the importance of elements of digital marketing in business nowadays (Kamal, 2016).

Moreover, Dobrescu (2018) showed profiling and recognizing the fundamental characteristics of organizations that employ digital marketing elements to promote their products regularly. For Romanian managers, digital marketing is a relatively new notion, with just about $53 \%$ of them being familiar with words from the field. Surprisingly, the statistic showed $21 \%$ of managers who said they had a high understanding of the three phrases ebusiness, e-commerce, and e-marketing and understood the need of having an online presence also said their company had a medium online presence and didn't have a digital marketing strategy in place. When asked if there is a variation between the meanings of the terms e-business, e-commerce, and e-marketing, $25 \%$ of those polled confessed that they don't know. The researcher also discovered that more than half of businesses perceive themselves to have a good internet presence, with the majority of them being older businesses founded before 1990 . Around $39 \%$ of the respondents with a strong web presence were older businesses. The data showed that, while it was predicted that younger companies would employ current digital marketing tools the most, it is obvious that the extra time and availability of founding had a greater impact on the usage of digital marketing tactics in the case of well-established organizations (Dobrescu, 2018).

\section{Dimensions of Entrepreneurial behaviour}

Entrepreneurial Tendencies and Interests.

The entrepreneurial tendency has several definitions. As cited in Ocak et al (2019), the entrepreneurial tendency is the combination of environmental and individual factors, and the commitment and desire of the person to work. Parnell, Crandall, and Menefee (1995) found that entrepreneurial tendency is closed related to three factors: the individual's level of 
knowledge and capability to take risks, the beliefs of the individual about business opportunities, and the self-confidence of the individual to examine the business opportunity. On the other hand, entrepreneurial interests are influenced by institutional (the vocation of course), social (social support), and personal aspects (strategic skills mastery) (Costa et al. 2009). Regardless, the entrepreneurial tendency and interest may differ as the environmental condition may be subjective for each individual (Ocak et al., 2019).

Interest is a motivator that can motivate a person to work harder and take advantage of available chances. Interest does not develop from birth; rather, it develops as a result of the events that influence it. Suhartini (2011) found that there is a positive relationship between income variables, feelings, and education on entrepreneurial interests, with the main factor of earning revenue. In addition, according to Ardiyani \& Kusuma (2016), the variables of attitude, education, and family environment have an impact on entrepreneurial interest. According to a study by Lestari and Wijaya (2012), entrepreneurship education has a favorable impact on students' entrepreneurial interests. Alma (2011) discovered that the environment, in the form of role models, has an impact on entrepreneurial interest. Entrepreneurial interest is defined as a person's ambition and readiness to work hard or attempt to achieve their requirements without fear of the risks that may arise and to always learn from their mistakes (Wulandari, 2013). If students are interested in entrepreneurial activities, they will have a strong desire to start their own business.

There are essentially no barriers to beginning a business using various internet networks or other social media that make it easy for the public to conduct buying and selling transactions, especially in the digital era. Because the interest contains an element of motivation or encouragement that drives students to conduct activities that follow the objectives, it will urge students to do a specific activity. A person's strong impulse can shift at any time. Thus, environmental (cultural) the elements influence not only the digital era and interests that can enable a person, especially a student, to become an entrepreneur (Suhartini, 2011). According to Karabulut (2016), personality traits had a favorable effect on the entrepreneurial interest, and personality could explain the entrepreneurial interest by $37 \%$ based on the results of component analysis and regression analysis. The findings of the study contradict those of Obschonka et al (2010), who found that personality does not influence the desire to establish a business. Then, in his research, Ajiwibawani (2017) discovered that Adversity Quotient has an impact on Student Entrepreneurship Attitudes. The study contradicts Bulmash's (2016) research, which revealed that adversity in entrepreneurship had a large and negative impact on satisfaction with the decision to become an entrepreneur.

\section{Attitudes in Starting a Business}

The attitude in starting a business refers to the desire of an individual that wants to become an entrepreneur which affects the intention of the individual to behave in a specific way. Thus, the attitude in starting a business is positively correlated with the entrepreneurial intention whereby the individual that has the positive mindset towards entrepreneurship prefers selfemployment (Mahmood et al., 2019). The rationale is that the more people believe they are receiving assistance from a company, the more they feel obligated to reciprocate in both attitudes and behaviors (Zampetakis et al., 2009). In a similar line, Hoogendoorn et al (2019) argue that when people perceive a lack of information assistance during the start-up phase, they will feel unsupported throughout the business startup process. The ambiguity associated 
with entrepreneurship activity is reduced by sharing knowledge and skills (McAdam \& Marlow, 2006).

Knowledge and consulting provided by business incubators, for example, can assist individuals in developing financial abilities and turning their ideas into commercial firms (Van Rijnsoever, 2020). Individuals' attitudes about entrepreneurship are likely to improve as a result of such assistance. Based on the existing researches, it is possible to argue that when nascent entrepreneurs perceive adequate support from local institutions, they are more likely to think positively about entrepreneurial activity, not only because they feel supported, but also because they develop a sense of reciprocity toward such institutions. Thus, Robinson et al. 1991, take a novel approach, embracing Ajzen and Fishbein's claim that an individual's attitude affects their appraisal. A programmed inclination that responds generally positively or negatively to the target of the attitude, according to Robinson et al. 1991. These authors also stress the need of changing one's mind throughout time. As a result, business attitudes can be characterized as predefined but changeable behavioral feelings and intents that span the development and management of a company.

Moreover, the degree to which a person has a favorable or unfavorable opinion of target behavior is reflected in their attitudes toward entrepreneurship (Ajzen, 1991). As a result, they reflect people's attitudes toward the possibility of starting a business (Zhang \& Cain, 2017). According to Kruger et al (2000), as an individual's view of the desirability of establishing a business grows, so does their entrepreneurial ambition. Such a relationship has been widely validated in the empirical literature, and in diverse circumstances. In Germany, India, Iran, Poland, Spain, and the Netherlands, for example, Moriano et al (2012) found that views about entrepreneurship were the largest determinant of entrepreneurial intention in all six nations studied. Karimi found a correlation between students' entrepreneurial intentions and their attitudes regarding entrepreneurship in Iran. In the Czech Republic, Hungary, Poland, and Slovakia, Nowiski et al (2019) discovered that a person's attitude toward entrepreneurship is a crucial predictor of entrepreneurial inclinations. Finally, Munir et al. (2019) found a beneficial impact of views on entrepreneurial ambitions when comparing Chinese and Pakistani students.

\section{Behavioral Control}

Behavioral control is the fact that indicate if there is a right to control how the employees do their job. Behavioral control is divided into 4 categories which are the type of instructions, degree of instruction, evaluation system, and the training process. Type of instruction refers to the employees being subjected to the business' instruction regarding the business processes. The degree of instruction refers to the extent to how detailed the instruction is to exert more control over the employees. Hence, lesser control indicates the instructions are not detailed. Next, the evaluation system. It refers to measuring the employees' performance. Lastly, the training process whereby indicates that the employees will need to do based on the business's criteria; therefore, periodic or ongoing training related to the business procedure would be implemented (Internal Review Service, 2021).

In Ajzen's (1991) theory of planned action, perceived behavioral control is the third and final predictor of intentions (TPB). It reflects the individual's perceived capacity to accomplish the goal actions and is linked to the ease or difficulty of performing the behaviour (Ajzen, 1987). Previous research has discovered a strong link between perceived behavioral control and the desire to start a business (Mathieson, 1991; Krueger et al., 2000; Autio et al., 2001; Souitaris et al., 2007; Gelderen et al., 2008; Gird and Bagraim, 2008; Linan et al., 2011; 
Solesvik et al., 2012). According to Ajzen (1991), perceived behavioral control is a factor that contributes to the apparent ease or difficulty of carrying out a behavior, and it accepts to reflect the previous understanding while also anticipating impediments and obstacles, implying that these elements reflect the perceptions that an activity will be difficult or impossible to carry out, as well as an expectation of impediments. The degree to which an individual influences conviction about the movement under investigation is determined by Perceived Behavioral control (Tsordia and Papadimitriou, 2015).

However, a recent study indicated that behavioral control refers to the individual's perception of the degree of difficulty to perform the behavior of interest. The point of view of behavioral control has been divided into 2 elements: self-efficacy and perceived controllability. Self-efficacy encompasses internal control factors like the individual's confidence to execute the task and perception of the task's difficulty. On the contrary, perceived controllability encompasses external control factors like opportunities, resources, and challenges (Vamyaka et al., 2020). A person's self-efficacy refers to their belief in their ability to complete a task or a collection of tasks (Bandura, 1977). Self-efficacy is a valuable concept for analyzing human behavior because research shows that it influences an individual's decision, the degree of effort, and perseverance (Chen et al., 2004). Simply put, those who have high self-efficacy for a task are more likely to pursue and then stick with that task than people who have low self-efficacy (Bandura, 1997).

\section{Social Learning Theory}

The Social Learning Theory introduced by Bandura has emphasized how our behavior is influenced by the environment through social and community norms, how behaviour is influenced by cognitive or personal factors (tendencies) through people's knowledge and observation, and also how our behavior influences the environment and constructs reinforcement and the opportunity to be seen by others (observational opportunity) by seeing and thinking that we have for a piece of information and vice versa. This theory is based on the idea that we learn from our interactions with others in a social context. Separately, people adopt comparable tendencies through witnessing the activities of others. People assimilate and mimic other people's behavior after witnessing it, especially if their observational experiences are favorable or include rewards related to observed conduct. Imitation, according to Bandura, entails the real replication of observed motor movements (Bandura, 1977). Direct reinforcement, according to Bandura, cannot account for all types of learning.

Based on the theory, Bandura included a social component in this theory, saying that people might learn new facts and behaviors by observing others. In SLT, there are three notions. For starters, humans can learn through observing others, which is referred to as observational learning. Second, mental states play a crucial role in learning and are referred to as intrinsic reinforcement. It also emphasizes that learning does not always result in a behaviour change, but rather follows the modeling process. Social learning theory is becoming more widely recognized as a critical component of long-term natural resource management and the promotion of desired behavioral change. Thus, the gap between "conventional learning theory" and "cognitive learning" is bridged by Social Learning Theory. It entails investigating how cognitive learning, or learning through doing, processing, and experiencing, affects how we learn. Bandura argues that humans are always learning and actively digesting information while also considering the implications (Bandura, 1977). 
In addition, SLT proposed that individuals, particularly students, modify their behavior by observing and imitating others. Rewards and punishments may have an impact on behavior during the learning process. This idea highlights the importance of the environment and student interactions in attracting a student's attention to a variety of options (Wenger, 2018). The theory of social learning links a student's assessments of his abilities to execute a task with his intention, implying that if he is confident in his ability to start a new business, that confidence may motivate him to do so. The idea identifies this as the relationship between entrepreneurship and intention if the student as an individual will not establish a business because he believes he is incapable of handling it. Observing others while learning, according to (Bandura, 1977), can lead to a shift in behavior. Several studies show that self-efficacy, as well as the quality of entrepreneurship instruction, have a crucial effect on student intention. This notion could explain a link between several aspects of entrepreneur's aim.

\section{Theory of Planned Behaviour (TPB)}

The TPB theory was pioneered by Ajzen (1991) and is an extension of the theory of reason for action. TPB theory explains that personal behavior is driven by behavioral intention, where behavioral intention is a function of three determinants, namely a person's attitude toward behavior, subjective norms, and behavioral control. In addition, according to (Agent, 1991) the control of one's intention will be formed by three main elements namely attitudes towards behavior, subjective norms and control of behavior combined. Attitude toward behavior means a measurement of an individual's degree of evaluation of the behavior in question. Whereas social pressure to implement or not implement a behavior is the meaning of subjective norms. Third, behavioral control refers to the individual's level of control over the behavior to be performed. According to TPB, the stronger the attitude, subjective norms, and control of behavior, the stronger the intention to perform the actual behavior. The TPB has been used to explain and predict intentions and behaviors in all types of research fields.

TPB theory explains that human behaviour depends on motivation i.e., their intentions and abilities (behavior control). Motivation and ability are the foundations that build theories related to aspiration levels, psychomotor performance and cognitive tasks, and other people's perceptions and attributions. These characteristics are also hallmarking of entrepreneurship, which is defined as deliberate and planned activity (Bird, 1988). In the context of entrepreneurship, entrepreneurship intention (EI) is described as a "selfacknowledged conviction" by any individual that he or she is willing to start a new company venture and that he or she is planning to do so in the future (Ridha and Wahyu, 2017; Thompson, 2009). The El is regarded as the initial stage in starting a new business (Kautonen, Van Gelderen, and Tornikoski, 2013).

However, individual differences appear to have an impact on El, according to the literature (Zhao and Seibert, 2006). As a consequence, personality traits have been thoroughly investigated by past researchers. Although personality qualities have been demonstrated to have a statistical relationship with entrepreneurship, previous research has found that their predictive usefulness is limited (Reynolds, 1997). Thus, the study shifted to cognitive models to describe the impact on entrepreneurial behavior (Scheier et al., 1994). According to the TPB model, three factors influence behavioral intentions: personal evaluation of behavior and its outcomes, which is referred to as attitude toward the behavior (Ajzen, 1991), alleged social pressure toward a behavior, which is referred to as subjective norms (SN) in TPB, and apparent difficulty in completing the behavior. It has been suggested that SN, PBC, and a positive attitude toward behavior work together to improve the intention to complete the 
behavior, which is referred to as PBC (Urban and Ratsimanetrimanana, 2015). In this study, actual behavior refers to entrepreneurial intent. Thus, through the use of TPB in this study, attitude toward behavior, subjective norms, and behavioral control were considered as predictors to determine students' entrepreneurial behavior.

\section{Linking Digital Marketing and Entrepreneurial Behaviour}

Nowadays, students are becoming more familiar with using digital technology and they know how to create, access, and exchange digital information (Ting, 2015). According to Greene, Yu, and Copeland (2014), being digitally literate entails not just being able to search and manage digital information, but also scrutinizing and integrating it. Even though that students nowadays are becoming more tech-savvy, many students are still struggling in using technology effectively. It can be concluded that the students are still need to learn the proper skills needed for information management which include planning, monitoring and controlling skills. Gilster (1957) also believes that to be digitally literate, one must not only know how to obtain information on the internet but also be able to comprehend and combine data from many print and digital sources. Digital literacy is more than simply knowing how to use technology; it also entails mastering ideas. While a student has high digital literacy, they are more confident and at ease when utilizing technology. On the other hand, a student with limited digital literacy will avoid utilizing digital technology.

According to a study conducted by Harding et al (2020), entrepreneurship in today's world requires skills and creativity in technology. The researchers examine four dimensions of technological readiness which include optimism, innovativeness, discomfort and insecurity. All of these dimensions are important to increase technological readiness among students and master digital marketing before embarking on digital entrepreneurship. It is important to have the right skills in using digital-based technology to support entrepreneurship. In the history of digital technology evolution, social media has been one of the world's fastesygrowing media. Every month, social media websites can reach over 1 billion visits (Richardson, Choong \& Parker, 2016). For instance, social media platforms such as Facebook are rapidly gaining popularity. Both private and individuals and business organizations can use the media to be advantageous. As mentioned by Stueber and Wurth (2017), the intricacy of the rapid evolution of this global digital environment is linked to consumer marketing and corporate management, including image and brand. Hence, students need to be skilled in using these platforms to encourage their entrepreneurial behavior.

Furthermore, students also need proper entrepreneurial education and training to become capable entrepreneurs. To be capable entrepreneurs, students must be capable of both technological and human aspects. There is a study conducted on the impact of entrepreneurship training combined with knowledge and skills in which the result shows that the students' entrepreneurial knowledge, attitudes and behavior skills increase. According to Hidayat and Saepudin (2016), institutional training may have an impact and influence on students' economic empowerment, as indicated by improved income and entrepreneurial prospects. improved income and entrepreneurial prospects (Hidayat \& Saepudin, 2016). As a result, educational innovators and social entrepreneurs will continue to work on reconstructing learning models and settings that will assist future entrepreneurs (Groff, 2013). In today's world, entrepreneurs must be able to take advantage of technological media in all aspects of their business, from manufacturing to marketing. According to a study, the success of a firm managed by entrepreneurs is inextricably linked to global trends (Grizane \& Jurgelane, 2017). Hence, the following hypothesis emerges. 


\section{Hypothesis}

Multiple linear regression was used to test the influence of digital marketing literacy on entrepreneurial behavior among Public University students. Although, according to Noh (2016) studies on general digital literacy among college students had found that there is no significant difference between demographic characteristics nor there are differences in information search or processes. In addition, another research has found that there is a low significant effect of digital literacy on entrepreneur behavior among the high-school students of Surabaya (Mudasih, Subroto \& Si, 2021). Thus, the research hypothesis is

H1: There is no significant influence of digital marketing literacy on student entrepreneurial behavior.

\section{Research Design}

This study employed an explanatory research design to find and explain causal relationships between digital marketing literacy and entrepreneurial behaviors among Public University students. Additionally, this study used a quantitative research method. To collect the data, a survey is used. A self-administered questionnaire is distributed online to the participants. According to Gurbuz (2017), a survey in the form of a quantitative method is commonly used to collect data by researchers due to the time constraint, low budget, mass target, and simple application. The distribution method was chosen because online surveys are cost-effective, and the insights gathered are often highly accurate (QuestionPro, 2021). Moreover, it is the most appropriate method to employ during this Covid-19 pandemic, thus, the questionnaires will be disseminated online using a Google Form. Additionally, as the respondents for this study are geographically diverse, an online survey is the ideal way to gather data. Kannan, Chang, and Whinston (1998) claimed that the internet allows online surveys to reach geographically diverse people.

\section{Methodology \\ The Sample}

The study population was Public University Malaysia students from various fields of study. Study samples were taken from four different Public Universities according to geographical areas in Peninsular Malaysia and they are randomly clustered. Cluster sampling is a type of random measurement, and is often applied to many different subsets of groups that are presented in a population that is large and the position is geographically distributed (Cavana, Delahaye, \& Sekaran, 2001). Researchers have difficulty in selecting samples individually from the population because it involves a high costs (Wiersma, 2005). It also creates homogeneity between groups and heterogeneity within groups. Public University students have been selected for admission centrally. To execute cluster random sampling, there are two steps; firstly, everyone in the population will be selected, then they will be separated according to a cluster. A cluster is a group of people that share similarities with each other, therefore, the cluster in this research refers to the selected students who are the same in terms of qualifications. Secondly, the selection of students using a group will be done using the random method, whereby the researcher will randomly choose a cluster to include in research (Investopedia, 2021). Lastly, the data collected using an online questionnaire had gathered 384 completed questionnaires. 


\section{Measures}

Data were collected using an online questionnaire. This questionnaire consists of three sections, namely: Section A: Respondents' Personal Information (Demographics), Section B: Digital Marketing Literacy and Section C: Entrepreneurial Behaviur. All items in the questionnaire were measured using a 5 -point Likert scale starting from scale 1 strongly disagree to scale 5 strongly agree.

The Digital Marketing Literacy construct consists of three sub-constructs measured using items adapted by (Nurfarahin, 2021; Faradillah, 2019; Sam, 2020). While the measurement items for entrepreneurial behavior such as attitudes toward behavior, subjective norms and behavioral control adapted from (Malebana and Swanepoel, 2019). Statistical Package for Social Science (SPSS) version 21 software was used to analyze the study data. By using SPSS, all the information has been released in the form of numbers and through that information, the relationship between factors can be seen more clearly whether it has a significant effect or vice versa. The method of data analysis conducted was descriptive analysis to analyze the demographics of the respondents and multiple linear regression analysis was used to test the hypothesis. Other than that, normality test and correlation analysis would also be conducted to analyse the data.

Cronbach's Alpha was used in this study to measure reliability. Cronbach's Alpha has values ranging from zero to one that has a measure of reliability value (Faizal \& Tze, 2017). Cronbach's Alpha has a reliability value above of 0.6 so the study is acceptable. Thus, if viewed in Table 1, the value of Cronbach's Alpha confidence coefficient recorded a score of 0.967 (digital marketing literacy) which represents the independent variable. Meanwhile, the dependent variable recorded a score of 0.991 (entrepreneurial behavior) which represents the dependent variable. In conclusion, the questionnaire involved in this study is acceptable and suitable to be conducted in the actual study field because the Cronbach's Alpha coefficient score for the independent variable is recorded more than of 0.6 .

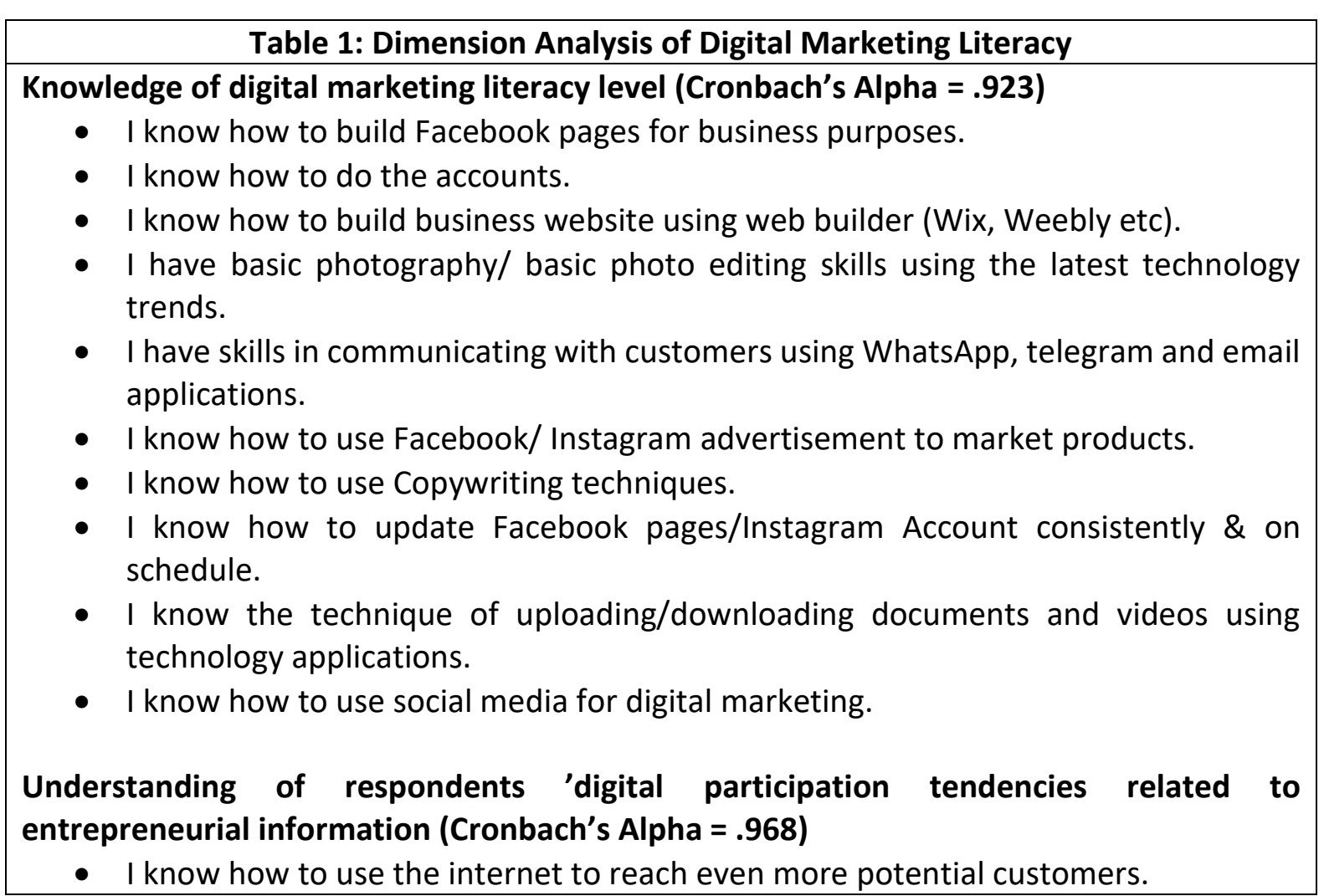


- I know how to use the internet because it is easy to connect with customers/suppliers.

- I know how to use the internet because of its low cost and ease in advertising the latest products.

- I know how to use the internet because of the high efficiency that makes it easy to get customer feedback.

- I know how to use the internet to get entrepreneurial information and the type of business or even the purpose of branding.

- I know how to use the internet to review the latest products on the market.

- I know using the internet to find information about suppliers.

- I know how to use the internet because it facilitates financial transactions through online banking for financial matters.

- I know how to use the internet because it facilitates financial transactions through online banking to receive payments from customers.

- I know how to use the internet because it facilitates financial transactions through online banking for suppliers/ advertisers.

Knowledge of the elements of digital marketing (Cronbach's Alpha $=.962$ )

- I know how to use digital marketing elements.

- I know how to use online advertising.

- I know how to use social media marketing.

- I know how to use email marketing.

- I know how to produce compelling business content on social media.

- I know how to use text marketing.

- I know how to use affiliate marketing.

- I know how to use Search Engine Optimization (SEO).

- I know how to use pay per click (PPC) advertising.

- The digital marketing element is an essential component of an online business.

\begin{tabular}{|l} 
Table 2: Dimension Analysis of Entrepreneurial Behavior \\
\hline Entrepreneurial Tendencies and Interests (Cronbach's Alpha = .988) \\
- I am willing to do anything to be an entrepreneur \\
- Entrepreneurship is my profession of choice and my dream career. \\
- I will work hard and have enough capital to open my own business firm someday. \\
- I am determined and very eager to start a business in the future. \\
- I have no problem and have no hesitation in starting my own business someday. \\
- I am planning and drafting my business affairs in the future. \\
- I am serious about starting a business in the future. \\
- I wasilities, skills and knowledge have influenced my interest in starting a business. \\
before I got involved in my studies. \\
Attitudes in Starting a Business (Cronbach's Alpha = .952) \\
- For me, digital entrepreneurs will provide more advantages and bring in profitable \\
- I returns than disadvantages.
\end{tabular}


- I will start my business if I am given the opportunity and have enough capital

- I prefer my own work, which is the field of entrepreneurship, rather than salaried work.

- In my view, the field of entrepreneurship gives me freedom to explore, gives me pleasure and satisfaction.

- I will seize the opportunity to be an entrepreneur because I am confident that I have the qualifications.

\section{Behavioural Control (Cronbach's Alpha $=.987$ )}

- The process of starting a business and keeping it running smoothly is very easy for me.

- I am confident I will be able to start my business process.

- I am confident I will be able to take full control of my business processes.

- I am willing to take risks and challenges throughout my business process.

- I have full knowledge of the procedures and documents required to start a business.

- I can start my business right away.

- I am confident that if I venture into business, I will succeed in this field.

- I'm confident I can spark new ideas to keep my business growing.

- I am confident that with the knowledge and qualifications I have I will be able to start and survive in the business world.

\section{Results}

Table 3 shows the respondents' background in which $82.3 \%$ of the respondents were female, $44.8 \%$ of the respondents were aged between $22-25$ years old, $54.4 \%$ of the respondents were Malay, $60.4 \%$ of the respondents were bachelor's degree holders, $42.2 \%$ of the respondents were in year $2,31.3 \%$ of the respondents were studying in Social Science field. Next, $57.6 \%$ of the respondents have entrepreneurship experience and $81.3 \%$ of the respondents used Facebook. However, $60.2 \%$ of the respondents never attended any entrepreneurship training or courses. Finally, $74.7 \%$ of the respondents have families that participates in entrepreneurship. 
Table 3: Respondents' Background

\begin{tabular}{|c|c|c|c|}
\hline \multirow{4}{*}{ Gender } & & Frequency & Percent \\
\hline & Male & 68 & 17.7 \\
\hline & Female & 316 & 82.3 \\
\hline & Total & 384 & 100.0 \\
\hline \multirow[t]{5}{*}{ Age } & $18-21$ years old & 85 & 22.1 \\
\hline & $22-25$ years old & 172 & 44.8 \\
\hline & $26-29$ years old & 64 & 16.7 \\
\hline & 30 years old and above & 63 & 16.4 \\
\hline & Total & 384 & 100.0 \\
\hline \multirow[t]{5}{*}{ Race } & Malay & 209 & 54.4 \\
\hline & Indian & 70 & 18.2 \\
\hline & Chinese & 59 & 15.4 \\
\hline & Others & 46 & 12.0 \\
\hline & Total & 384 & 100.0 \\
\hline \multirow[t]{5}{*}{ Education level } & Bachelor's Degree & 232 & 60.4 \\
\hline & Master's Degree & 111 & 28.9 \\
\hline & $\mathrm{PhD}$ & 26 & 6.8 \\
\hline & Others & 15 & 3.9 \\
\hline & Total & 384 & 100.0 \\
\hline \multirow{6}{*}{ Year of study } & Year 1 & 81 & 21.1 \\
\hline & Year 2 & 162 & 42.2 \\
\hline & Year 3 & 79 & 20.6 \\
\hline & Year 4 & 28 & 7.3 \\
\hline & Year 5 & 34 & 8.9 \\
\hline & Total & 384 & 100.0 \\
\hline \multirow[t]{6}{*}{ Field of study } & Social Science & 120 & 31.3 \\
\hline & Science & 63 & 16.4 \\
\hline & Marketing & 108 & 28.1 \\
\hline & Language & 55 & 14.3 \\
\hline & Technical & 38 & 9.9 \\
\hline & Total & 384 & 100.0 \\
\hline \multirow[t]{3}{*}{ Entrepreneurship experience } & Yes & 221 & 57.6 \\
\hline & No & 163 & 42.4 \\
\hline & Total & 384 & 100.0 \\
\hline \multirow{5}{*}{$\begin{array}{l}\text { Entrepreneurship medium } \\
\text { being used }\end{array}$} & Facebook & 312 & 81.3 \\
\hline & Instagram & 218 & 56.8 \\
\hline & Telegram & 89 & 23.2 \\
\hline & WhatsApp & 229 & 59.6 \\
\hline & Total & 384 & 100.0 \\
\hline \multirow{3}{*}{$\begin{array}{l}\text { Attending entrepreneurship } \\
\text { courses or training }\end{array}$} & Yes & 153 & 39.8 \\
\hline & No & 231 & 60.2 \\
\hline & Total & 384 & 100.0 \\
\hline \multirow{3}{*}{$\begin{array}{l}\text { Family participation in } \\
\text { entrepreneurship }\end{array}$} & Yes & 287 & 74.7 \\
\hline & No & 97 & 25.3 \\
\hline & Total & 384 & 100.0 \\
\hline
\end{tabular}


Table 4 shows the reliability analysis for digital marketing literacy and entrepreneurial behavior. Based on the result, both variables have a high reliability with a value of 0.967 and 0.991 respectively.

Table 4: Reliability Analysis

\begin{tabular}{|l|l|l|}
\hline Variable & Cronbach's Alpha & No. of Items \\
\hline Digital marketing literacy & 0.967 & 30 \\
\hline Entrepreneurial behavior & 0.991 & 24 \\
\hline
\end{tabular}

The results of the data normality distribution based on the Skewness statistical test and Kurtosis are shown in Table 5 . The result indicates that the variables are normally distributed i.e. has the test result of the variable in between \pm 2 standard deviations. Therefore, the data in this study are suitable for further analysis to be performed.

Table 5: Normality Test

\begin{tabular}{|c|c|c|c|c|}
\hline \multirow{2}{*}{ Variable } & \multicolumn{2}{|c|}{ Skewness } & \multicolumn{2}{c|}{ Kurtosis } \\
\cline { 2 - 5 } & Statistic & Std. Error & Statistic & Std. Error \\
\hline Digital marketing literacy & -.333 & .125 & -.573 & .248 \\
\hline Entrepreneurial behavior & -.235 & .125 & -1.261 & .248 \\
\hline
\end{tabular}

Table 6 shows the descriptive analysis for digital marketing literacy and entrepreneurial behavior as a whole. The result shows that digital marketing literacy scores $(\min =3.78, \mathrm{SD}=0.765)$ in among UA students is at a moderate level. Meanwhile, entrepreneurial behavior scores $(\min =3.12, S D 1.215)$ among UA students is at a moderate level.

Table 6: Descriptive Analysis

\begin{tabular}{|c|c|c|c|}
\hline & Min & SD & Level \\
\hline $\begin{array}{c}\text { Digital marketing } \\
\text { literacy }\end{array}$ & 3.78 & .765 & Moderate \\
\hline $\begin{array}{c}\text { Entrepreneurial } \\
\text { behavior }\end{array}$ & 3.12 & 1.215 & Moderate \\
\hline
\end{tabular}

Table 7 shows the result of the correlation analysis between digital marketing literacy and entrepreneurial behavior variables $(r=0.638$, sig $=.000)$ which shows that there is a positive and significant relationship between digital marketing literacy and entrepreneurial behavior.

Table 7: Correlation Analysis of Digital Marketing Literacy on Entrepreneurial Behavior Variables

\begin{tabular}{|c|c|c|}
\hline \multirow{2}{*}{ Digital Marketing Literacy } & \multicolumn{2}{|c|}{ Entrepreneurial Behavior } \\
\cline { 2 - 3 } & $\mathbf{r}$ & Sig \\
\hline
\end{tabular}

Table 8 shows that the digital marketing literacy dimension predicted significantly on students 'entrepreneurial behavior, $R 2=0.519, F(3,380)=136.519, p<0.05$. All of these predictors accounted for $51.9 \%$ of the variance in students 'entrepreneurial behavior. Further analysis found that knowledge of digital marketing literacy level, Beta $=0.279, \mathrm{t}(380)=4.412$, $\mathrm{p}<0.01$; understanding of respondents 'digital participation tendencies related to entrepreneurial information, Beta $=0.176, \mathrm{t}(380)=4.030, \mathrm{p}<0.01$; and knowledge of digital marketing elements, Beta $=0.559, \mathrm{t}(380)=9.496, \mathrm{p}<0.01$ significantly influenced students 'entrepreneurial behavior. These findings suggest that all three dimensions of digital marketing literacy contribute to students 'entrepreneurial behavior. Thus, $\mathrm{H} 1$ is rejected. 
Hence, when students have high knowledge in digital marketing literacy level, high understanding of digital participation, and high knowledge of digital marketing elements, it would encourage the students' entrepreneurial behavior.

Finally, the results of the study also found that there are still a handful of students who are not fully proficient in the elements of digital marketing. The small number of votes through the questionnaire indicates that the digital marketing element consists of online advertising, email marketing, social media marketing, text messaging, affiliate marketing, search engine optimization (SEO) and pay-per-click (PPC) advertising are still not mastered by a handful of students. The findings from the multiple linear regression test by which the influence of digital marketing literacy on entrepreneurial behavior had concluded that all three dimensions of digital marketing literacy influence Public University students' entrepreneurial behavior.

Table 8: Multiple Regression Analysis of Digital Marketing Literacy on Entrepreneurial Behavior Variables

\begin{tabular}{|l|c|c|c|}
\hline \multicolumn{1}{|c|}{ Dependable Variables } & Beta & t & Significance \\
\hline Knowledge of digital marketing literacy level & 0.279 & 4.412 & .000 \\
\hline $\begin{array}{l}\text { Understanding of respondents' digital } \\
\text { participation tendencies related to } \\
\text { entrepreneurial information }\end{array}$ & -0.176 & -4.030 & .000 \\
\hline Knowledge of the elements of digital marketing & 0.559 & 9.496 & .000 \\
\hline \multicolumn{2}{|c|}{$\mathrm{R} 2=0.519 ; \mathrm{F}(3,380)=136.519$, Sig. F $=0.000$} \\
\hline
\end{tabular}

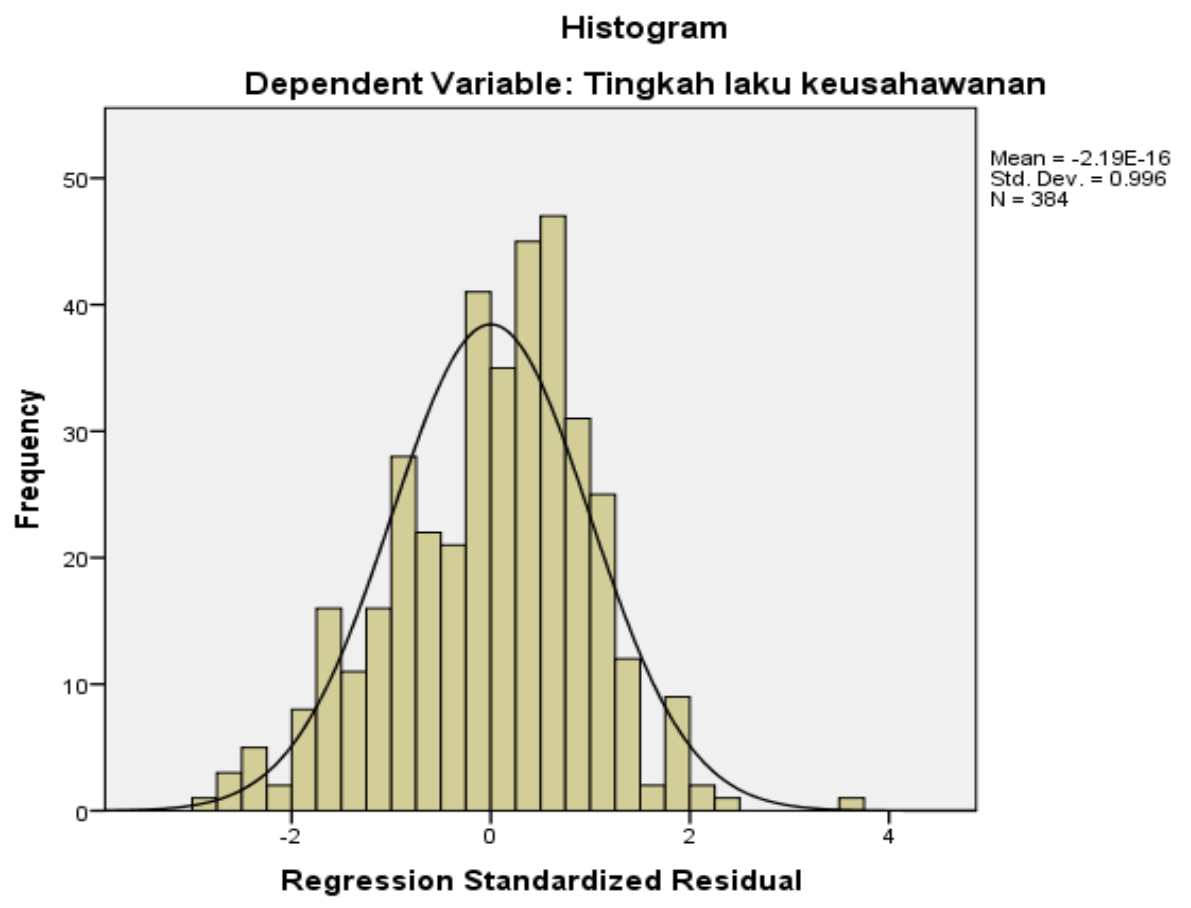



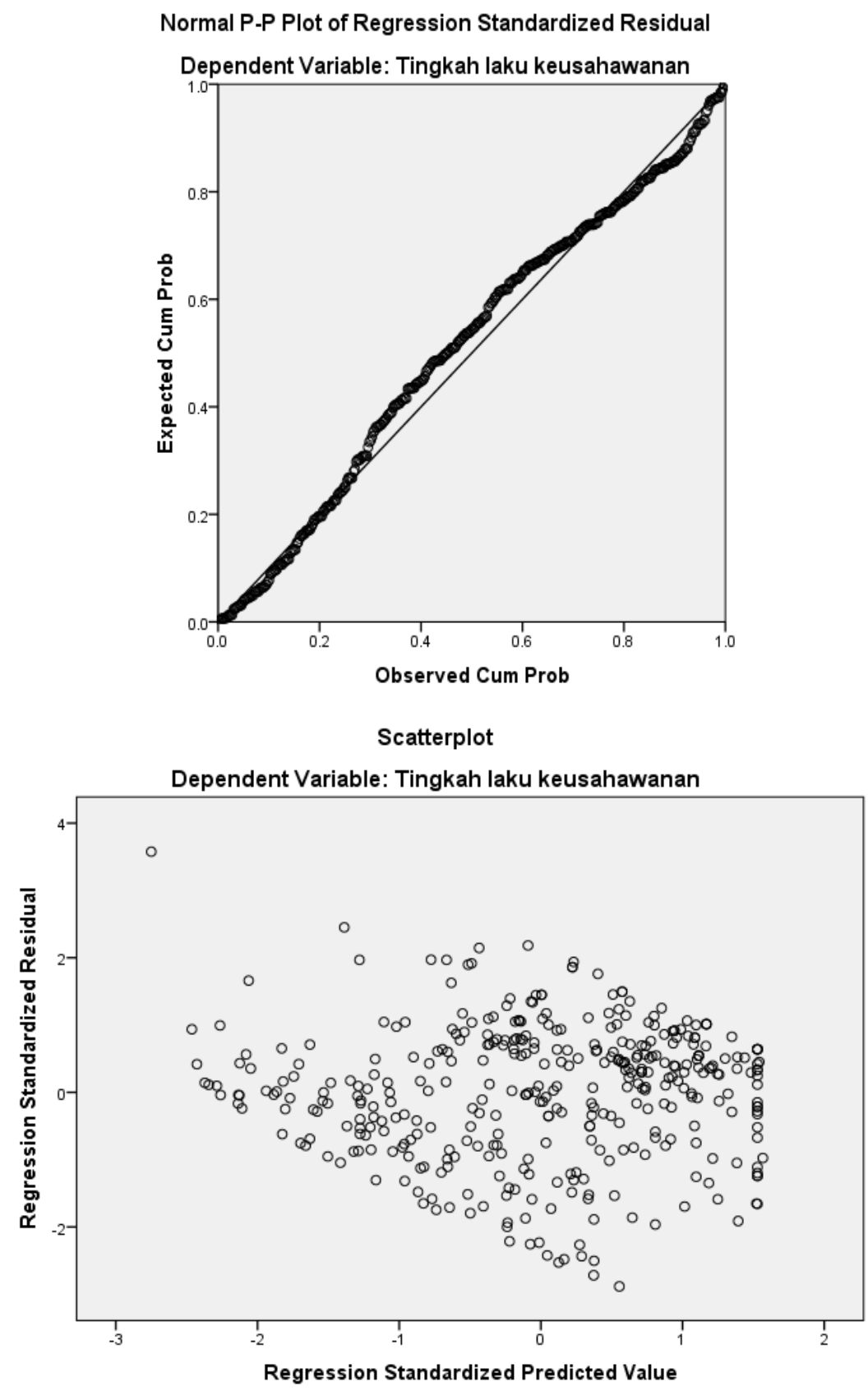

\section{Discussion}

The hypothesis of this study indicated that there is no significant influence of digital marketing literacy on student entrepreneurial behavior. However, the hypothesis is rejected in which the results show that there is a significant influence of digital marketing literacy on student entrepreneurial behavior. The findings of this study can also be further strengthened by a study conducted by Low et al (2020) who studied the factors of digital marketing in Malaysia. Based on his study, Malaysian digital marketing factors can obtain more information about customers, facilitate dialogue to reach customers, provide communication speed, efficiency to further improve services to customers as well as help sales to exist customers. Sepasgozar et al (2019); Shareef et al (2009) implied that the advantages and convenience of technology have a positive impact on the acceptance of the use of digital technology that influences the positive impact of student entrepreneurial behavior. 
These findings are also in line with the general framework developed by Mohd Osman on the process of becoming an entrepreneur requires specific knowledge and skills that represent digital marketing literacy in this study. In addition, technical skills, namely specific skills, and techniques are important things that need to be taken into account in the field of marketing as stated by (Shahrir, 2015). Moreover, the study verdicts showed positive results, however, it still highlights a significant weak influence in determining entrepreneurial behavior due to lack of exposure to students' skills and knowledge of digital marketing elements.

As such, digital marketing literacy of formulated students is still at a moderate level. Ultimately, there is a positive relationship between digital marketing literacy and students' entrepreneurial behavior. When the student's digital marketing skills, knowledge or literacy are high, they tend to venture into the field of entrepreneurship and discover promising opportunities in this field.

\section{Conclusion}

In conclusion, although past research had shown no or less significance between digital marketing literacy and entrepreneurial behavior, this research had rejected its hypothesis as a result of further analysis through all the three dimensions of digital marketing literacy; in which they directly and positively influence the Public University students' entrepreneurial behavior. Digital marketing literacy is very important for an entrepreneur in the business world. It was found that the lack of exposure to the digital marketing element had put the students at a disadvantage, where they are unable to seize opportunities in business. Digital marketing literacy of Public University Malaysia students is at a moderate level, therefore, the research showed that there is a positive influence between the digital marketing literacy with attitudes towards behavior, subjective norms and perceived behavioral control towards entrepreneurial intentions among students based on Social Learning Theory and Planned Behaviour Theory (TPB).

The implications of this study are important to provide awareness to Public University students about the importance of increasing digital marketing literacy that will influence entrepreneurial behavior to venture into the field of entrepreneurship. It also reveals information on the elements of digital marketing that are important in undertaking entrepreneurial activities in the current era. This study can also encourage the university to take steps to cultivate certain knowledge to increase student involvement in entrepreneurship.

\section{Acknowledgements}

This research was funded by Universiti Kebangsaan Malaysia under grant code: GG-2020- 007.

\section{References}

Ajzen, I. (1991). The theory of planned behavior. Organizational behavior and human decision processes, 50(2), 179-211.

Ala-Mutka, K. (2011). Mapping Digital Competence: Towards a Conceptual Understanding. Luxembourg: Publications Office of the European Union.

Bizhanova, K., Mamyrbekov, A., Umarov, I., \& Orazymbetova, A. (2019). Impact of digital marketing development on entrepreneurship. E3S Web of Conferences, 135(1).

Cavana, R., Delahaye, B., \& Sekaran, U. (2001). Applied Business Research: Qualitative and Quantitative Methods (3rd ed.). Australia: John Wiley \& Sons. 
Costa, F. J. D., Soares, A. A. C., \& Bonfirm, D. G. (2009). Factors of influence on the entrepreneurial interest: an analysis with students of information technology related courses. JISTEM Journal of Information Systems and Technology Management, 6(2), 227-246.

Education Development Center (EDC). (2021). Media Literacy \& Digital Literacy. Retrieved from https://sites.google.com/view/literasi-digital-kemanusiaan/bahan-ajar/literasimedia-digital-literacy.

Gilster, P. (1997). Digital literacy. Wiley.

Gurbuz, S. (2017). Survey as a quantitative research method. Retrieved from https://www.researchgate.net/publication/321874371_Survey_as_a_Quantitative_Re search_Method

Greene, J. A., Yu, S. B., \& Copeland, D. Z. (2014). Measuring Critical Components of Digital Literacy and their Relationships with Learning. Computers \& Education, 76, 55-69.

Grizane, T. \& Jurgelane, I. (2017). Social media impact on business evaluation. Procedia Computer Science, 104, 190-196.

Groff, J. (2013). Technology-rich innovative learning environments. OECD Innovative Learning Environments Project, 1-30.

Harding, D., Kadiyono, A. L., Hafiar, H., Ma'mun, T. N., Wibowo, H., Nugraha, Y., \& Siswadi, A. G. P. (2020). Readiness of Technology Adaptation Towards Digital-Based Entrepreneurship. International Journal of Entrepreneurship, 24(1), 1-5.

Hidayat, D., \& Saepudin, A. (2016). Locally-Based enterprise training to improve the economic empowerment of the learners. Journal Sosial Dan Pembangunan, 32(2), 292-301.

Internal Review Service. (2021). Behavioral Control. Retrieved from https://www.irs.gov/businesses/small-businesses-self-employed/behavioral-control

Investopedia. (2021). Systematic sampling vs. cluster sampling: what's the difference?. Retrieved from https://www.investopedia.com/ask/answers/051815/what-differencebetween-systematic-sampling-and-cluster-sampling.asp

Kamal, Y. (2016). Study of Trend in Digital Marketing and Evolution of Digital Marketing Strategies. International Journal of Engineering Science and Computing, 6(5), 53005302.

Kannan, P. K., Chang, A-M. and Whinston, A. B. (1998). Marketing information on the I-way: data junkyard or information gold mine?. Communications of the ACM, 41, 35-43.

Lamberton, C., \& Stephen, A. T. (2016). A Thematic Exploration of Digital, social media, and Mobile Marketing: Research Evolution from 2000 to 2015 and an Agenda for Future Inquiry. Journal of Marketing, 80(6), 146-172.

Mahmood, T. M. A. T., Mamun, A. A., \& Ibrahim, M. D. (2019). Attitude towards entrepreneurship: a study among Asnaf Millennials in Malaysia. Asia Pacific Journal of Innovation and Entrepreneurship, 14(1), 2-14.

Malabana, M. J., \& Swanepoel, E. (2019). Graduate entrepreneurial intentions in the rural provinces of South Africa. Southern African Business Review, 19(1), 89-111.

Malik, R. (2017). An Empirical Study of Digital Marketing and its Elements. International Journal of Scientific Research in Science and Technology, 3, 715-718.

Martin, C. A. (2005). From high maintenance to high productivity: What managers need to know about Generation Y. Industrial and Commercial Training, 37(1), 39-44. 
Abdullah, M. F. N. L., \& Wei, L. T. (2017). Validity and Reliability Form One Geometry Learning Self -Assessment Instrument. Malaysian Journal of Learning and Instruction, 14(1), 211265.

Abdullah, M. S. (2015). Factors influencing diploma students Polytechnic engineering in venturing into the field of entrepreneurship. Masters Technical Education, Faculty of Technical and Vocational Education, Universiti Tun Hussien Onn Malaysia.

Mudasih, I., Subroto, W. T., \& Si, S. M. (2021). The effect of financial literacy, digital literacy, and entrepreneurial learning outcome on entrepreneur behavior of students at smk negeri 1 surabaya. Technium Social Science Journal, 15(1), 303-320.

Noh, Y. (2016). A study on the effect of digital literacy on information use behavior. Journal of Librarianship and Information Science, 1-31.

Ocak, S., Şahin, T., \& Gider, Ö. (2019). Entrepreneurial Tendency of the Students: A Research on the Students of the Department of Physiotherapy and Rehabilitation and Nutrition and Dietetics. Journal of Entrepreneourship and Development, 14(1), 67-77.

Organisation for Economic Cooperation and Development (OECD). (2019). The Missing Entrepreneurs 2019: What potential does digital entrepreneurship have for being inclusive? Retrieved from https://www.oecd-ilibrary.org/industry-and-services/themissing-entrepreneurs-2019_28e047baen;jsessionid=jbuF27ihi6ZhulmKR4YD9M09.ip-10-240-5-113

Parnell, A. J., Crandall, W., \& Menefee, M. (1995). Examining the Impact of Culture on Entrepreneurial Propensity: An Empirical Study of Prospective American and Egyptian Entrepreneurs. Academy of Entrepreneurship Journal, 1(1), 39-53.

QuestionPro. (2021). Research design: definition, characteristics, and types. Retrieved from https://www.questionpro.com/blog/research-design/

QuestionPro. (2021). Survey research: definition examples, and methods. Retrieved from https://www.questionpro.com/article/survey-research.html

Richardson, P. S., Choong, P., \& Parker, M. (2016). Social media marketing strategy: Theory and research propositions. Journal of Marketing Development and Competitiveness, 10(2), 24-34.

Stueber, H., \& Wurth, S. (2017). A literature review of marketing and Facebook [Unpublished master's thesis]. Halmstad University.

Taiminen, H., \& Karjaluoto, H. (2015). The usage of digital marketing channels in SMEs. Journal of Small Business and Enterprise Development, 22(4), 633-651.

Ting, Y. (2015). Tapping into Students' Digital Literacy and Designing Negotiated Learning to Promote Learner Autonomy. Internet and Higher Education, 26, 25-32.

Vamyaka, V., Stoforos, C., Palaskas, T., \& Botsaris, C. (2020). Attitude toward entrepreneurship, perceived behavioral control, and entrepreneurial intention: Dimensionality, structural relationships, and gender differences. Journal of Innovation and Entrepreneurship, 9(5). https://doi.org/10.1186/s13731-020-0112-0

Wiersma, W., \& Jurs, S. G. (2005). Research methods in education: An introduction. Ally and Bacon.

Zenebe, A., Alsaaty, F. M., \& Anyiwo, D. (2017). Relationship between individual's entrepreneurship intention, and adoption and knowledge of information technology and its applications: An empirical study. Journal of Small Business \& Entrepreneurship, 30 (2), 215-232. 